\title{
PENINGKATAN PRESTASI BELAJAR DAN RESPON SISWA MATERI SPLTV MENGGUNAKAN MODEL PEMBELAJARAN GROUP INVESTIGATION PADA SISWA KELAS X MIPA 4 SMA N 1 BANGUNTAPAN
}

\author{
Suranten \\ SMA Negeri 1 Banguntapan \\ rantenkisma@gmail.com
}

\begin{abstract}
Abstrak: Penelitian ini bertujuan untuk meningkatkan prestasi belajar dan respon siswa pada materi sistem persamaan linear tiga variabel dengan menerapkan model Pembelajaran Group Investigation pada siswa klas X MIPA 1 semester gasal SMA Negeri 1 Banguntapan Bantul Tahun Pelajaran 2019/2020. Proses penelitian diawali dengan metode observasi yang dilakukan oleh peneliti, observer dan subyek penelitian. Pengumpulan data dilakukan dua tahap yaitu data hasil penilaian tengah semester gasal tahun 2019/2020 sebagai data awal, serta data akhir hasil penilaian harian setelah dilakukan tindakan. Penelitian ini menggunakan instrument lembar observasi keterlaksanaan proses pembelajaran, angket dan lembar soal test. Jumlah subyek dalam penelitian ini adalah 36 peserta didik. Penelitian tindakan dengan model Group Investigation berlangsung selama 2 siklus dengan 2 kali pertemua setiap siklus dan satu kali penilaian. Analisa data menggunakan metode analisis diskriptif kuantitatif pada data yang berupa angka dan diskripsi kualitatif pada data hasil observasi yang perlu dianalisis secara sederhana untuk mendeskripsikan fakta yang terjadi. Hasil penelitian menunjukkan model pembelajaran Group Investigation dapat diterapkan dengan baik dan terjadi peningkatan prestasi belajar dan respon siswa dari siklus 1 dan siklus 2 .
\end{abstract}

Kata kunci: prestasi belajar, respon siswa, group investigation

\section{IMPROVING STUDENT'S ACHIEVEMENT AND RESPONSE IN LINEAR EQUATION SYSTEM WITH THREE VARIABLES BY USING GROUP INVESTIGATION IN CLASS X MIPA 4 SMA N 1 BANGUNTAPAN}

\begin{abstract}
This study aims to improve student achievement and response material in the threevariable linear equation system by applying the Group Investigation Learning Model to the 10th grade Mathematics and Natural Sciences students of SMA Negeri 1 Banguntapan Bantul in the 2019/2020 Academic Year. The research process begins with an observation method conducted by researchers, observers and research subjects. The data collection was carried out in two stages, namely the results of the odd semester 2019/2020 midterm assessment data as preliminary data, and the final data on the results of the daily assessment after the action was taken. This study used an observation sheet for the implementation of the learning process, a questionnaire and a test question sheet. The number of subjects in this study were 36 students. Action research with the Group Investigation model lasted for 2 cycles with 2 times each of each cycle and one assessment. Data analysis uses quantitative descriptive analysis methods in the form of numerical data and qualitative descriptions of observational data that need to be analyzed simply to describe the facts that occur. The results showed the Group Investigation learning model can be applied well and an increase in student achievement and response from cycle 1 and cycle 2.
\end{abstract}

Keywords: learning achievement, student response, group investigation

\section{PENDAHULUAN}

Prestasi Matematika siswa klas X MIPA 4 SMA N 1 Banguntapan tergolong masih rendah hal ini terlihat dari jumlah siswa yang mencapai kriteria ketuntasan minimal pada penilaian tengah semester gasal 2019/2020 hanya 7 orang dari 36 siswa masih kurang dari $60 \%$.

Proses pembelajaran yang tidak terorganisir dengan baik mengakibatkan aktivitas belajar siswa yang kurang kondusif.
Hal ini nampak pada partispasi siswa selama pembelajaran yang rendah dan penyelesaian tugas individu yang tidak lengkap baik dari sisi jumlah siswa yang mengumpulkan ataupun jumlah tugas yang diselesaiakan.

Berdasarkan kondisi di atas terdapat kesenjangan antara kenyataan di lapangan dengan kondisi ideal yang diharapkan. Suatu pembelajaran yang ideal di era global harus dapat memberi dan memfasilitasi bagi tumbuh 
dan berkembangnya ketrampilan intelektual, sosial, dan personal bagi siswa( Sugiyanto, 2010: 12). Salah satu contoh pembelajaran ideal adalah model pembelajaran cooperatif learning.

Pembelajaran cooperatif learning cocok bagi siswa karena model ini menciptakan interaksi yang asah, asih dan asuh sehingga tercipta masyarakat belajar. Dalam pembelajrana matematika model kooperatif learning perlu mempertimbangkan materi yang dipelajari . Apakah materi yang dipelajari saling menjadi prasyarat atau tidak. Materi SPLTV didalam menentukan penyeleasaian tidak saling bergantung satu dengan yang lain hal ini meungkinkan untuk menggunakan model Group Investigation

Berdasarkan masalah diatas rumusan masalah pada Penelitian Tindakan Kelas ini adalah 1) Bagaimana penerapan model pembelajaran Group Investigation materi sistem persamaan linear tiga variabel pada siswa kelas X MIPA 4 tahun Pelajaran 2019/2020? 2) Apakah penerapan model pembelajaran Group Investigation materi sistem persamaan linear tiga variabel pada siswa kelas X MIPA 4 tahun Pelajaran 2019/2020 dapat meningkatkan prestasi belajar siswa? 3) Apakah penerapan model pembelajaran Group Investigation materi sistem persamaan linear tiga variabel pada siswa kelas X MIPA 4 tahun Pelajaran 2019/2020 dapat meningkatkan respon siswa?

Prestasi belajar siswa merupakan hasil belajar yang didapat siswa berdasarkan tujuan pembelajaran (winkel, 1991:319) Prestasi belajar dapat diamati pada hsil belajar yang dibagi dalam 5 bagian yaitu informasi verbal, ketrampilan dan intelektual, strategi kognitif, sikap dan ketrampilan motoris (Gagne: 1978: 49-50).

Menurut Caraway kompetensi dan prestasi belajar matematika juga dipengaruhioleh sikap siswa terhadap matematika (White, et al, 2006: 36). Selanjutnya prestasi belajar dapat pula dipandang sebagai pencerminan dari pembelajaran yang ditunjukan oleh siswa melalui perubahan-perubahan dalam bidang pengetahuan/pemahaman, keterampilan, analisis, sintesis, evaluasi serta nilai dan sikap (Soejanto, 1979: 12).

Prestasi belajar siswa ditentukan oleh dua faktor yaitu intern dan ekstern. Faktor intern merupakan faktor-faktor yang berasal atau bersumber dari siswa itu sendiri, sedangkan faktor ekstern merupakan faktor yang berasal atau bersumber dari luar peserta didik. Faktor intern meliputi prasyarat belajar, yakni pengetahuan yang sudah dimiliki oleh siswa sebelum mengikuti pelajaran berikutnya, keterampilan belajar yang dimiliki oleh siswa yang meliputi cara-cara yang berkaitan dengan mengikuti mata pelajaran, mengerjakan tugas, membaca buku, belajar kelompok mempersiapkan ujian, menindaklanjuti hasil ujian dan mencari sumber belajar, kondisi pribadi siswa yang meliputi kesehatan, kecerdasan, sikap, cita-cita, dan hubungannya dengan orang lain. Faktor ekstern antara lain meliputi proses belajar mengajar, sarana belajar yang dimiliki, lingkungan belajar, dan kondisi sosial ekonomi keluarga (Usman, 1995: 12).

Dapat disimpulkan secara umum bahwa prestasi belajar adalah hasil yang telah dicapai siswa dalam proses pembelajaran yang memuaskan, dan hasilnya bisa dinyatakan secara kualitatif maupun kuantitatif yang dapat dideskripsikan.

Mengukur prestasi belajar siswa pada dasarnya adalah mengecek apakah hasil belajar sudah sesuai dengan tujuan pembelajaran atau belum (Winkel, 1991: 319). Kesesuaian tersebut masih memiliki suatu tingkatan/gradasi, apakah sesuai sekali, sesuai, agak sesuai, ataukah kurang sesuai. Kesesuaian ini menentukan tingkat prestasi belajar yang dimiliki seorang siswa.

Respon merupakan gerakan-gerakan yang terkoordinasi oleh persepsi seseorang terhadap peristiwa-peristiwa luar dalam lingkungan sekitar menurut (Hamalik 2011: 39). Sedangkan siswa menurut Depdiknas merupakan suatu komponen penting dalam suatu proses pembelajaran, respon sebagai perilaku yang merupakan konsekuensi dari perilaku yang sebelumnya sebagai tanggapan atau jawaban suatu persoalan atau masalah tertentu (Soekanto, 1993: 48). Dalam pembelajaran siswa tidak hanya berinteraksi dengan salah satu sumber belajar, tetapi mungkin berinteraksi dengan keseluruhan sumber belajar yang dipakai untuk mencapai tujuan pembelajaran yang dipakai (Hamalik 2011:2). Siswa bisa dikatakan sebagai seseorang yang berperan penting dalam proses pembelajaran.

Menurut Eagly, A.H. \& Chaiken respon seseorang dibedakan menjadi 3 yaitu cognitive responses, affective responses, dan behavioral 
responses. Cognitive responses terkait dengan apa yang diketahuiborang tersebut tentang objek sikap. Affective responses berkaitan dengan perasaan atau emosi seseorang berkaitan dengan objek sikap. Behavioral responses berkaitan dengan tindakan yang muncul ketika menghadapi objek sikap (Widoyoko, 2018: 103)

Dari teori diatas dapat disimpulkan bahwa respon siswa adalah gerakan yang dilakukan oleh siswa terhadap hal yang dialami dalam hal ini adalah prose pembelajaran matematika yang terkait dengan perintah dari guru atau teman ataupun tugas selama pembelajaran di dalam kelompok khususnya dan di dalam kelas pada umumnya.

Model pembelajaran kooperatif merupakan suatu model pembelajaran yang mendukung berkembangnya ketrampilan sosial siswa sekaligus aspek kognitif. Model pembelajaran ini memiliki 5 tahap pembelajaran yaitu 1) mengklarifikasi dan estlablishing set 2) mempresentasikan informasi/ mengorganisasikan siswa ke dalam kelompok-kelompok belajar, 3) membantu kerja kelompok belajar, 4) mengujikan berbagai materi, dan 5) memberikan pengakuan (Sugiyanto, 2010: 6)

Group Investigation yang dirancang oleh Herbert B. Thelen yang diperluas dan diperbaiki oleh Sharn dan kawan-kawannya merupakan metode yang paling kompleksdan kooperatif dibanding metode Jigsaw dan STAD karena siswa sudah terlibat di dalam perencanaan dan pemilihan materi. Metode ini menuntut siswa memiliki kemampuan yang baik di dalam berkomunikasi, ketrampilan di dalam kerja kelompok. Kelompok pada Group Investigation akan menyelesaikan tugas yang telah dipilih dengan segenap kemampuan yang dimiliki dengan pantauan guru dan fasilitas apabila diperlukan. Hasil kerja kelompok yang merupakan analisa dan sintesa kemudian dipresentasikan di depan kelas untuk ditanggapi kelompok lain dan disimpulkan bersama guru. Setelah semua kelompok tampil guru membuat kesimpulan akhir dan mengevalusai mengenai kontribusi kelompok terhadap penyelesaian tugas kelas dan kontribusi individu terhadap kelompok. Ada banyak tipe pembelajaran kooperatif salah satunya adalah Group Investigation.

Penerapan model Group Investigation dalam pembelajaran sistem persamaan linear tiga variabel dilaksanakan dengan langkah- langkah 1) Membagi kelompok dan materi yang dikehendaki masing-masing kelompok, 2) Siswa berdiskusi dalam kelompok 3) Siswa mempresentasikan hasil belajar dalam kelompok, 4) Penyimpulan hasil akhir dan 5) Evaluasi. Guru di dalam pembelajaran kooperatif sebatas sebagai fasilitator dalam kelompok kecil yang bekerjasama dalam memaksimalkan kondisi belajar untuk mencapai tujuan. Salah satu tujuan di dalam pembelajaran adalah peningkatan prestasi.

Dalam memudahkan perincian tujuan pembelajaran di dalam kelas, tujuan-tujuan yang hendak dicapai seorang siswa dirumuskan dalam Kompetensi Inti (KI) dan Kompetensi Dasar (KD) (dalam kurikulum 2013/kurtilas). Untuk memerinci KD sehingga lebih operasional dijadikan butir-butir indikator. Indikator pencapaian kompetensi menjadi penanda apakah seorang siswa telah dapat mencapainya atau belum.

Teknik evaluasi prestasi belajar biasanya menggunakan tes. Tes dibuat berdasarkan indikator yang menjadi tujuan pembelajaran. Tes dapat diarahkan untuk member informasi data kuantitatif maupun kualitatif tergantung dari kemampuan apa yang ingin diketahui. Tes lisan dan tes tertulis biasa digunakan dalam testing hasil belajar di ranah kognitif yaitu prestasi pengetahuan, pemahaman, penerapan, analisa, sintesa dan evaluasi. Salah satu bentuknya adalah tes obyektif dengan menggunakan soal atau pernyataan tertutup yang biasanya berbentuk ragam betul-salah, menjodohkan, atau pilihan ganda. Data yang dihasilkan dari tes semacam ini bersifat kuantitatif.

Karakteristik matematika merupakan ilmu universal yang mendasari perkembangan teknologi modern, mempunyai peran penting dalam berbagai bidang kehidupan dan membantu mengembangkan kemampuan atau daya berpikir manusia (BSNP, 2006). Materi sistem persamaan linear tiga variabel di SMA merupakan kelanjutan dari materi sistem persamaan linear dua variabel yang sudah dipelajari di SMP sehingga secara umum pengetahuan prasyarat sudah dimiliki siswa. sistem persamaan linear tiga variabel dapat diselesaikan paling tidak dengan 4 cara yaitu eliminasi, substitusi, determinan matriks dan campuran antara eliminasi dan substitusi. Ketiga cara ini tidak saling bergantung di dalam mempelajari sehingga model Group Investigation bisa diterapkan. 
Prestasi yang akan diraih tidak terlepas dari tujuan pembelajaran matematika untuk Sekolah Menengah Atas (SMA) dan Madrasah Aliyah menurut Badan Standar Nasional memiliki kemampuan dalam hal: (1) memahami konsep-konsep matematika, menjelaskan ketekaitan antar konsep, dan menggunakan konsep tersebut dalam menyelesaikan soal atau masalah, (2) menggunakan penalaran, melakukan manipulasi, serta menyusun bukti, (3) memecahkan masalah antara lain mampu memahami masalah, merancang model matematika, menyelesaikan model, serta menafsirkan solusinya, (4) menyajikan gagasan matematis dengan simbol, tabel, diagram, atau media lain, dan (5) memiliki sikap menghargai kegunaan matematika dalam kehidupan. Untuk mencapai tujuan itu matematika memiliki kompetensi pengetahuan dan ketrampilan (Kemdikbud: 2016).

Belajar merupakan aktivitas mental/ Psikis yang berlangsung dalam interaksi aktif dengan lingkungan, yang menghasilkan perubahan pengetahuan-pemahaman, ketrampilan dan nilai sikap. Perubahan sebagai hasil belajar bersifat permanen dan konstan (Winkel, 1987: 36). Sedang mengajar adalah memberikan berbagai ilmu yang bermanfaat bagi perkembangankemampuan berfikirnya (Uyoh saduloh, 2015: 7). Ketika Siswa belajar dan diajar maka akan nampak perubahan yang dapat diukur yang biasa disebut prestasi belajar. Walau proses berfikirnya tidak nampak.

Siswa SMA pada perkembangan belajar sudah sampai pada tahap operasi formal sehingga sudah mulai bisa berfikir abstrak, penalaran yang kompleks, dapat menguji hipotesis dalam mental (Sutirna: 2013: 29). Siswa pada masa ini sudah bisa berdiskusi dan mengkomunikasikan dan mengambil kesimpulan dengan arahan guru.

Berdasarkan rumusan masalah yang telah ditetapkan tujuan Penelitian Tindakan Klas ini adalah 1) Untuk meningkatakan prestasi belajar siswa kelas X MIPA 4 materi sistem persamaan linear tiga variabel dengan menerapkan model pembelajaran Group Investigation. 2) Untuk meningkatakan respon siswa kelas X MIPA 4 materi sistem persamaan linear tiga variabel dengan menerapkan model pembelajaran Group
Investigation. 3) Untuk mengetahui penerapan model pembelajaran Group Investigation dalam materi sistem persamaan linear tiga variabel.

Ruang lingkup dalam penelitian ini terbatas pada mata pelajaran matematika yang dilaksanakan pada materi sistem persamaan linear tiga variabel. Materi tersebut berada pada KD.3.3 Menyusun sistem persamaan linear tiga variabeldari masalah kontekstual dan KD 4.4 Menyelesaikan masalah kontekstual yang berkaitan dengan sistem persamaan linear tiga variabel. merupakan materi pada mata pelajaran matematika Kelas X semester gasal pada kurikulum 2013.

Penelitian ini termasuk penelitian tindakan kelas yang telah dilaksanakan sebanyak 2 siklus, dimana pada setiap siklusnya terdiri dari atas 4 tahapan, yaitu tahap merencanakan (planning), tahap melaksanakan (acting), tahap mengamati (observing), dan tahap merefleksi (reflecting). Pada akhir setiap satu siklus dilakukan penilaian dan pengisian angket respon siswa terhadap pembelajaran. Penilaian pada siklus 1 dengan mengerjakan soal tes. Respon siswa terhadap pembelajaran dengan pengisian angket bertujuan untuk mengetahui ketercapain indikator yang telah ditetapkan dan perbaikan tindakan yang diperlukan pada siklus 2. Penilaian pada siklus 2 dengan mengerjakan soal tes. Respon belajar siswa dengan pengisian angket bertujuan untuk mengetahui ketercapain indikator yang telah ditetapkan. Hasil penilaian dari siklus 2 bisa untuk mengetahui keberhasilan perbaikan tindakan yang telah dilakukan.

Definisi operasional yang ada pada penelitian tindakan klas ini adalah prestasi belajar yang dinyatakan dalam bentuk nilai atau dalam bentuk skor, setelah siswa mengikuti pelajaran matematika, respon belajar adalah tanggapan yang diberikan oleh anak ketika mengikuti pembelajaran secara langsung. Respon yang baik akan memberikan hasil pembelajaran yang baik.

Metode kooperatif adalah suatu pengajaran yang melibatkan siswa untuk bekerja dalam kelompok-kelompok untuk menetapkan tujuan bersama. Salah satu metode ini adalah Group Investigation, yaitu suatu metode pembelajaran yang melibatkan siswa sejak dari perencanaan sampai topik yang akan dipelajari. 


\section{METODE PENELITIAN}

Penelitian Tindakan Kelas atau Classroom Action Research merupakan penelitian kualitatif yang dilakukan untuk menghadapi berbagai masalah dan isu pendidikan. Penelitian ini menggunakan siswa dan guru sebagi obyek penelitian yang di luar orbit kehidupan.

Menurut Hopkins Penetitian Tindakan Kelas adalah penelitian yang mengkombinasikan prosedur penelitian dengan tindakan subtantif, suatu tindakan yang dilakukan dalm disiplin inkuiri atau suatu usaha seseorang untuk memahami apa yang terjadi sambai terlibat dalam sebuah proses perbaikan dan perubahan. Penelitian ini akan membantu seseorang dalam mengatasi secara praktis persoalan yang dihadapi dalam situasi darurat dan membantu pencapaian tujuan ilmu sosial dengan kerjasama dalam kerangka etika yang disepakati bersama. Sedangkan menurut Kemmis Penetitian Tindakan Kelas adalah sebuah bentuk inkuiri reflektif yang dilakukansecara kemitraan mengenai situasi sosial tertentu untuk meningkatkan rasionalitas dan keadilan dari: 1) kegiatan praktek sosial atau pendidikan mereka; 2) pemahaman mereka mengenai kegiatan-kegiatan praktek pendidikan; dan 3) situasi yang memungkinkan terlaksananya kegiatan praktek ini. Secara jelas Ebbut mengemukaan Penelitian Tindakan Kelas adalah kajian sistematik dari upaya perbaikan pelaksanaan praktekpendidikan oleh sekelompok guru dengan melakukan tindakantindakan dalam pembelajaran berdasarkan refleksi mereka mengenai hasil dari tindakantindakan tersebut (Wiriaatmadja, 2010: 12).

Menurut Ebutt dalam Wiriatmadja (2010: 12) dalam satu siklus meliputi perencanaan, tindakan, pengawasan dan pemeriksaan. Berdasarkan hasil siklus I apabila hasil pengawasan dan pemeriksaan di dalam refleksi masih terdapat kekurangan maka hasil refleksi siklus I dapat digunakan sebagai masukan untuk perbaikan siklus II.

\section{Waktu dan Tempat Penelitian}

Penelitian tindakan ini dilakukan pada semester gasal tahun pelajaran 2019/2020 dari bulan Agustus sampai dengan bulan November 2019 di SMA N 1 Banguntapan.

\section{Subjek Penelitian}

Subyek penelitian siswa klas X MIPA 4 SMA N 1 Banguntapan, terdiri dari 36 siswa meliputi 22 perempuan dan 14 laki-laki. Obyek penelitian ini adalah peningkatan prestasi belajar dan respon siswa materi sistem persamaaan linear tiga variabel dengan menggunakan model Pembelajaran Group Investigation.

\section{Prosedur Penelitian}

Penelitian Tindakan Kelas ini merupakan penerapan dari model pembelajaran Group Investigation. Peneliti mengawali dengan pengamatan hasil penilaian tengah semester dan karakteristik siswa serta materi yang akan dipelajari. Kegiatan pembelajaran dengan group investigation diawali demgan presentasi guru, pembentukan kelompok pemilihan materi diskusi kelompok dan presentasi hasil setiap kelompok. Setelah diskusi kelompok dilakukan penilaian individual antar siklus. Setelah seluruh kelompok tampil dilakukan penilaian akhir siklus. Siswa juga mengisi angket respon belajar untuk mendapatkan data respon belajar siswa.

Data, Instrumen, dan Teknik Pengumpulan Data

Data pada penelitian tindakan kelas meliputi data nilai penilaian tengah semester sebagai data awal sebelum dilakukan tindakan. Data respon siswa terhadap proses pembelajaran selama siklus berlangsung, efektifitas RPP dan LKS yang digunakan dalam pembelajaran, serta data nilai prestasi siswa pada penilaian antar siklus dan penilaian pada akhir siklus.

Data respon siswa, data efektifitas proses pembelajaran, data efektifitas RPP dan LKS merupakan data kualitatif, sedang data prestasi siswa merupakan data kuantitatif.

Alat pengumpulan data respon siswa terhadap pembelajaran berupa angket yang terdiri 10 butir pernyataan dengan skala Likert 4 alternatif jawaban.

Tabel 1. Kategori respon siswa terhadap pembelajaran

\begin{tabular}{lll}
\hline No & Interval & Kategori \\
\hline 1 & $31-40$ & Amat baik \\
2 & $21-30$ & Baik \\
3 & $11-20$ & Jelek \\
4 & $1-10$ & Amat Jelek \\
\hline
\end{tabular}

Proses pembelajaran dengan lembar observasi dan angket dengan 4 alternatif jawaban.

Tabel 2. Efektivitas Pembelajaran model GI

\begin{tabular}{lll}
\hline No & Interval & Kategori \\
\hline 1 & $31-40$ & Amat baik \\
2 & $21-30$ & Baik \\
3 & $11-20$ & Jelek \\
4 & $1-10$ & Amat Jelek \\
\hline
\end{tabular}


Efektifitas RPP dan LKS yang digunakan selama siklus berlangsung berupa angket yang disusun dengan menggunakan skala Likert dengan 4 alternatif jawaban 1 sampai 4 .

Tabel 3. Efektivitas LKS dan RPP Materi SPLTV

\begin{tabular}{lll}
\hline No & Interval & Kategori \\
\hline 1 & $25-32$ & Amat baik \\
2 & $17-24$ & Baik \\
3 & $9-16$ & Jelek \\
4 & $1-8$ & Amat Jelek \\
\hline
\end{tabular}

Sedangkan prestasi siswa diukur dengan instrumen tes soal berbentuk uraian terdiri atas 4 soal dengan kategori higher order thingking skill (HOTS).

Pengumpulan data observasi proses pembelajaran dilakukan dengan pengamatan pada pertemuan 1, 2, 4 dan 5. Pengumpulan data respon siswa, efektifitas RPP, dan LKS dikumpulkan setiap akhir pertemuan 2 dan 5 . Data respon siswa diambil dengan menggunakan angket yang telah diisi oleh siswa setiap berakhirnya siklus 1, 2. Data pelaksanaan tindakan menggunakan lembar observasi selama siklus 1,2 , dan wawancara dengan 2 siswa setiap berakhirnya siklus 1, 2 . Sedangkan data prestasi siswa dikumpulkan pada penilaian menggunakan instrumen tes yang dikerjakan oleh siswa pada pertemuan 3 dan 6. Hasil penilaian dibandingkan antara siklus 1 dan 2 sehingga menjadi data prestasi siswa pada pembelajaran Sistem Persamaan Linear Tiga Variabel.

\section{Indikator Keberhasilan}

Indikator keberhasilan penelitian tindakan kelas ini adalah: (1) Peningkatan prestasi belajar siswa yaitu $60 \%$ atau lebih siswa berhasil mencapai KKM (67) pada materi materi sistem persamaan linear tiga variabel. Peningkatan prestasi belajar siswa materi sistem persamaan linear tiga variabel dengan menggunakan model pembelajaran group investigation. (2) Peningkatan respon siswa terhadap pembelajaran yaitu $80 \%$ atau lebih siswa memiliki respon terhadap pembelajaran yang baik dengan rentang respon siswa terhadap pembelajaran lebih dari 21-30 dari skor total 40. (3). Penerapan model pembelajaran group investigation yang berjalan dengan baik.

\section{HASIL DAN PEMBAHASAN}

Hasil Observasi Pelaksanaan Pembelajaran Pelaksanaan penelitian tindakan kelas dibantu oleh seorang guru matematika sebagai observer. Berdasarkan pengamatan observer pada pertemuan siklus 1 guru menyampaiakn rencana pembelajaran dan tujuan yang akan dicapai.setelah siswa memahami rencana pembelajaran dan tujuan yang akan dicapai guru membentuk kelompok. Kelompok yang sudah terbentuk kemudian memilih materi yang sudah disiapkan. Guru membagikan Lembar kerja siswa sesuai dengan pilihan kelompok masingmasing. Selama diskusi kelompok berlangsung guru mengamati dan berkeliling untuk menjadi fasilitator bagi kelompok yang memerlukan. Guru mengkonfirmasi setiap kelompok tentang kesimpulan yang di dapat selama diskusi kelompok.

Pada pertemuan kedua siklus 1 guru mempersilakan salah satu kelompok yang sudah siap untuk mempresentasikan hasil kerja kelompok di depan kelas. Kelompok yang sudah siap adalah kelompok determinan. Selama diskusi guru memantau pelaksanaan diskusi kelas. Setelah siswa mempresentasikan guru memberikan penguatan dan membuat kesimpulan bersama dengan siswa dilanjutkan pengisian angket respon siswa terhadap proses pembelajaran.

Setelah siklus 1 berakhir, pada pertemuan ketiga guru memberikan penilaian harian 1 untuk mengetahui prestasi belajar siswa dengan 4 soal pengetahuan dan 2 soal ketrampilan dengan kategori HOTS berbentuk uraian.

Hasil observasi siklus 2 dimulai pada pertemuan siklus 4 guru mempersilakan kelompok yang sudah siap untuk mempresentasikan hasil diskusi kelompok di depan kelas, kelompok yang sudah siap yaitu kelompok dengan materi menyelesaikan sistem persamaan tiga variabel dengan eliminasi. Selama diskusi kelas berlangsung guru memantau pelaksanaan diskusi dan pada akhir pembelajaran guru memberikan penguatan dan membuat kesimpulan bersama dengan siswa. Pada pertemuan kelima guru mempersilakan kelompok yang belum presentasi yaitu kelompok dengan materi menyelesaikan sistem persamaan tiga variabel dengan substitusi. 
Pada pertemuan kelima guru mempersilakan salah satu kelompok mempresentasikan hasil diskusi kelompok di depan kelas. Tampil sebagai pemateri pertama kelompok dengan materi menyelesaikan sistem persamaan linear tiga variabel dengan metode Eliminasi. Guru memfasiltasi agar diskusi kelas dapat berjalan dengan baik sesuai rencana dan hasil yang diharapkan. Setelah 2 kelompok tampil pada akhir diskusi guru bersama siswa membuat kesimpulan hasil diskusi kelas tentang menyelesaikan sistem persamaan linear tiga variabel dengan metode eliminasi.

Pada pertemuan keenam guru memberikan penilaian harian terkait materi menyelesaikan 4 butir soal sistem persamaan linear tiga variabel berbentuk uraian dengan metode yang sudah dipelajari. Guru memantau pelaksanaan penilaian agar siswa mengerjakan dengan jujur dan fokus pada lembar soal dan lembar jawaban masing-masing karena soal dibagi secra mengular dengan 2 macam soal yang berbeda. Sehingga mengurangi tingkat ketidakjujuran siswa selama penilaian.

Penentuan peningkatan prestasi setiap siswa dilakukan dengan membandingkan hasil penilaian pada siklus 1 dan siklus 2. Penentuan peningkatan respon siswa terhadap pembelajaran dilakukan dengan membandingkan hasil pengisian angket dari siklus 1 dan 2 .

Setelah siswa mengikuti serangkaian tahap pembelajaran dengan metode group investigation pada materi sistem persamaan tiga variabelsiswa mengisi angket respon siswa terhadap pembelajaran dan mengikuti penilaian pada setiap siklus sebagai penilaian harian. Data prestasi siswa dari siklus 1 dan siklus 2 mengalami peningkatan yang dapat dilihat dari tabel berikut:

Tabel 4. Data Penilaian

\begin{tabular}{|c|c|c|c|}
\hline \multirow{2}{*}{ No } & \multirow{2}{*}{ Rentang Nilai } & \multicolumn{2}{|c|}{ Jumah (\%) } \\
\hline & & Siklus 1 & Siklus 2 \\
\hline 1. & J67-100 & $18(51)$ & $25(69)$ \\
\hline 2. & J0-66 & 17(49) & $11(31)$ \\
\hline
\end{tabular}

Peningkatan prestasi peserta didik dari siklus 1 dan siklus 2 dapat dilihat pada digram berikut:
PRESTASI SISWA

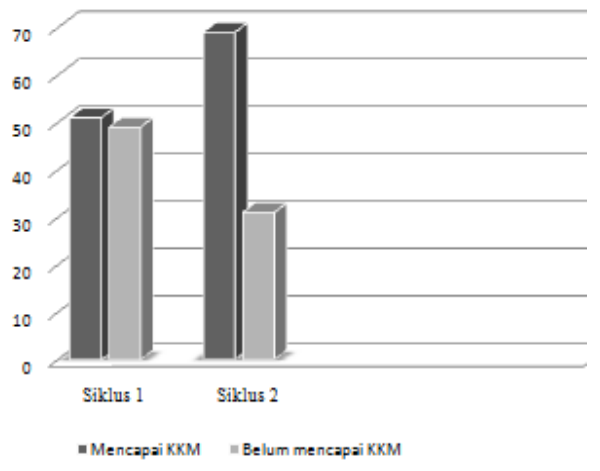

Gambar 2. Diagram Peningkatan prestasi

Siswa dari siklus 1 ke siklus 2

Berdasarkan diagram di atas jumlah siswa yang mencapai KKM dari siklus 1 sebesar $55 \%$ sehingga indikator keberhasilan penelitian belum tercapai.presatsi siswa pada siklus 2 sebesar 69\% sehingga meningkat sebesar $18 \%$ dan indikator keberhasilan penelitianberupa peningkatan presasi siswa lebih dari 60\% mencapai KKM telah tercapai.

Berdasarka hasil pengisian angket siswa yang diisi setelah berakhinya siklus 1 dan 2 mengalami peningkatan pada siswa dengan repon amat baik hal ini dapat dilihat dari tabel sebagai berikut:

Tabel 5. Data Respon Siswa

\begin{tabular}{clll}
\hline \multirow{2}{*}{ No } & \multirow{2}{*}{ Rentang Nilai } & \multicolumn{2}{c}{ Jumah (\%) } \\
\cline { 3 - 4 } & & Siklus 1 & \multicolumn{1}{c}{ Siklus 2 } \\
\hline 1 & $31-40$ & $9(26)$ & $12(33)$ \\
2 & $21-30$ & $26(74)$ & $24(67)$ \\
3 & $11-20$ & $0(0)$ & $0(0)$ \\
4 & $1-10$ & $0(0)$ & $0(0)$ \\
\hline
\end{tabular}

Hasil peningkatan respon siswa terhadap pembelajaran dapat dilihat pada diagram berikut :

RESPON SISWA

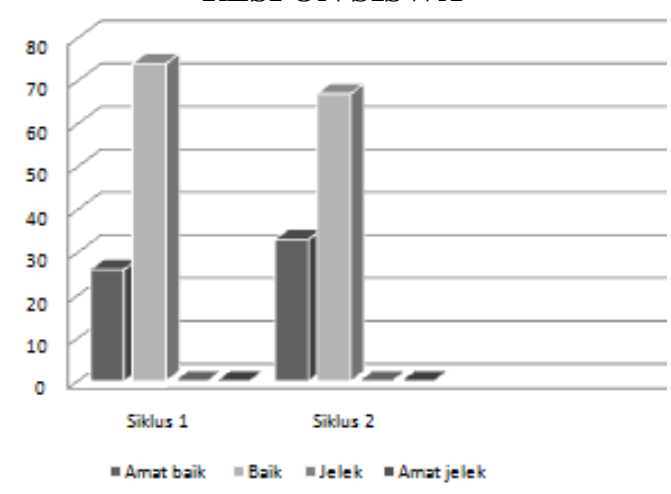

Gambar 3. Diagram Peningkatan Respon Siswa dari siklus 1 ke siklus 2 
Berdasarkan diagram di atas jumlah peserta didik yang memiliki respon amat baik pada siklus 1 sebesar $26 \%$ dan respon baik sebesar $74 \%$ secara indikator keberhasilan penelitian sudah tercapai yaitu $80 \%$ atau lebih siswa memiliki respon baik. Respon siswa pada siklus 2 respon amat baik $33 \%$ dan respon baik $67 \%$. Pada siklus 2 respon siswa amat baik mengalami peningkatan sebesar $7 \%$. Dengan demikian indikator penelitian peningkatan respon respon siswa terhadap pembelajaran juga telah tercapai.

Berdasarkan pengamatan observer selama pembelajaran berlangsung penerapan metode pembelajaran group investigation materi sistem persamaan linear tiga variabel pada kelas X MIPA 4 tahun 2019/2020 berlangsung sesuai sintak yang ada yaitu meliputi pembentukan kelompok, pemilihan materi, diskusi kelompok sesuai rencana kerjasama implementasi dan analisa sintesa, dan diskusi klas untuk penyajian akhir dan Evaluasi terhadap pekerjaan klas scara keseluruhan.

\section{SIMPULAN}

Berdasarkan data pengamatan observer selama pembelajaran penerapan model pembelajaran Group Investigation, pada materi sistem persaman linear tiga variabel dengan langkah-langkah pembelajaran meliputi selesksi topik, merencanakan kerjasama, implementasi, analisa dan sintesa, penyajian hasil akhir dan evaluasi selanjutnya telah dilaksanakan pada siswa kelas X MIPA 4 tahun pelajaran 2019/2020. Meningkatkan prestasi belajar siswa dari siklus 1 ke siklus 2 pendukung dari hasil penilaian dan keterlaksanaan pembelajaran sebesar $18 \%$ dan lebih $60 \%$ siswa berhasil mencapai KKM (67) pada siswa kelas X MIPA 4 tahun pelajaran 2019/2020.

Model pembelajaran Group Investigation dapat meningkatkan respon pembelajaran siswa dari siklus 1 dan 2 secara keseluruhan baik yaitu lebih $80 \%$ siswa memiliki respon pembelajaran yang tinggi, dan mengalami peningkatan pada respon amat baik sebesar $9 \%$ pada materi sistem persamaan linear Tiga Variabel pada siswa kelas X MIPA 4 tahun pelajaran 2019/2020.

\section{DAFTAR PUSTAKA}

Budiyanto, M.A.K. (2016). Sintaks 45 Model Pembelajaran dalam Student Centeret Learning. Malang: UMM Press.

Depdiknas. (2008) Kamus Besar Bahasa Indonesia. Jakarta: Balai Pustaka

Gagne, R.M. (1978). Principles of instructional design. Chicago: Holt, Rinehart, and Winston.

Jhonson, D.W., and Jhonson R.T. (2002). Meaningfull assessment: a manageable and cooperative process. Boston: Allyn Bacon.

Kemdikbud, (2016). Standar Penilaian. Jakarta: Kemdikbud.

Kemdikbud, (2016). Standar isi. Jakarta: Kemdikbud.

Kemdikbud, (2016). Standar Proses. Jakarta: Kemdikbud.

Oemar Hamalik. (2011). Proses Belajar Mengajar. Jakarta: Bumi Aksara.

Soekanto, Soerjono (1993) Sosiologi Suatu Pengantar. Jakarta: Rajawali Pers

Sugiyanto, (2010). Model-model pembelajaran Inovatif, Solo: Yuma Pustaka

Sugiyono, (2017). Metode Penelitian Pendidikan, Bandung: Alfabeta

Sutirna. (2013). Perkembangan dan Pertumbuhan Peserta Didik, Yogyakarta: Andi Offset

Usman, Uzer. (1995). Menjadi guru profesional. Bandung: Remaja Rosdakarya.

Sadulloh, Uyoh, dkk. (2015) Pedagogik, Bandung: Alfabeta

White, et al. (2006). Mathematics Attitude, Beliefs, and Achievement in Primary Preservice Mathematics, Teacher Education. Mathematics Teacher Education and Development. Vol 7.pp 33-52.

Widoyoko, S.E.P.(2018) Teknik Penyusunan Instrumen, Yogyakarta: Pustaka Pelajar

Winkel, W. S. (1991). Psikologi pengajaran, Jakarta: Grasindo

Wiriatmadja Rochiati, (2010). Metode Penelitian Tindakan Kelas, Bandung: PT Remaja Rosda Karya 